\title{
Role of Spirituality in Harmony at Workplace: A System Approach
}

\author{
Faize Ali Shah, Research Scholar, Department of Management, Faculty of Social Sciences, Dayalbagh \\ Educational Institute, (Deemed University), Dayalbagh, Agra, Uttar Pradesh, India. \\ Shivangi Agarwal, Teacher, Holy Public Group of Schools, Shastripuram, Agra, Uttar Pradesh, India.
}

Abstract: In this pace of time, people often get some moments for themselves in their busy schedule. That's the main reason behind increasing frustration and depression levels in the society. Our life is full of challenges and competitions whether we are at home or at workplace. So, it becomes a compulsion to work on a new paradigm which lessens this frustration level of the people. To answer this question many researchers or scholars came up with an idea of spirituality. In spite of being a traditional phenomenon, the concept of spirituality is getting high significance in this modern era. This is because of its unique nature of providing strength in pain. There are many people who are following spiritual practices as their routine activity. Workplace is the only place after our home where we spent most of our time. That's why people want to practice spirituality not only at home but at their workplace also. On the other side, organizations find it difficult to maintain harmony and peace among the members of organization. So, they are also gaping the practices of spirituality to maintain the optimized level of harmony in the organization. Through this paper researcher determine the leading factors of spirituality in harmony at workplace and also find out the relationship between them.

Keywords - Harmony, Spirituality, System Approach and Workplace

\section{INTRODUCTION}

Competition in the world came into existence since very immemorial time, the reason behind it is, the survival of only the fittest in the world ${ }^{[10]}$. Globalization results in commencement of many challenges for the firms as they have to lay especial focus on the speed innovation to fulfill the increasing demands of customers ${ }^{[17]}$. Not only the organizations but also the workers of the firms have to face many challenges weather directly or indirectly for their positions, recognition, promotions etc that gives rise to many unavoidable conflicts and threatens the peace and progress of a workplace ${ }^{[10]}$. Due to these issues employees experience lots of stress and pressure in their working life. Studies found that prayer and meditation plays an important role in relieving a person from various diseases and social pressure ${ }^{[11]}$ and spirituality is the combination of various prayers and meditation practices. Spirituality directly affects our physical and mental well being ${ }^{[2]}$. Currently people wants to practice spirituality not only in their personal lives but also in their work life as they spend large portion of their time in working ${ }^{[13]}$. That's why many researchers are now focusing on linking spirituality and religion with organizational commitment, team performance, employee wellbeing and ethical behavior, like various organizational activities ${ }^{[14]}$. The workplace spirituality fulfills the deep desires of an individual and society to find ultimate purpose of life and to live their life accordingly ${ }^{[3]}$. Spirituality gives meaning to our life. Workplace Spirituality is simply a journey of collaboration and integration of management theories with the concept of spirituality ${ }^{[9]}$. Initiating spirituality at workplace results in engagement of employees both physiologically and psychologically ${ }^{[20]}$. Now, it is the skill of an employer how he/she incorporate an atmosphere in the organization which have a proper balance between spiritual and organizational goals. This integration further highlighted some other concepts such as morality, truth, and honesty in business and management practices that indicates emergence of this paradigm ${ }^{[12]}$. In an organization spirituality has two dimensions i.e. individual spirituality, through which an employee possesses faith in the organization and has a sense of trustworthiness and the other is organizational spirituality, through which organization strives to achieve excellence ${ }^{[20]}$. Spirituality is all about sharing and experiencing the attachment and togetherness with the people of the organization ${ }^{[5]}$. Today is the world of dynamic business environment whereby, authorities of the organizations are relying and convincing people to form teams and create team-based structures for the introduction of creative ideas and solutions ${ }^{[4]}$.

Evidences in recent times have showed that the frequency of strikes have been increased causing disruption at workplace. This is due to the colliding relations of management and worker ${ }^{[15]}$. As the disputes are increasing it becomes necessary for the management to think out of the 
box. One solution to this problem is creating a harmonious atmosphere in the organization. Harmony means a state of peace, that can be achieved when there is absence of strikes and entrust among the employees ${ }^{[6]}$. Prof. K. R. Subramanian, D.S.Chaubey \& Rani Ramaswamy defines harmony as "the way parts combine well together or into a whole". Generally, this term is used in music when a composer is composing music with various notes and harmony is the stage where he achieves a perfect combination of notes and results in the formation of a pleasing sound. Just like 'Musical Harmony' it's very important to create harmony among the management and the employees as it the secret principle to control life especially at organizational level ${ }^{[18]}$. The managers and subordinates are the key players of an organization. Good leaders help to stimulate, motivate, encourage, and recognize their followers in order to get key performance results and bad leaders on the other hand de-motivate employees, leading to strikes and grievances which creates disharmony ${ }^{[10]}$. Harmony is a collective word which focuses on teamwork and spirituality says if we please only ourselves we'll experience limited happiness but if we live for others we'll encounter inner happiness which is infinite ${ }^{[8]}$. So, it is clear from the above context that harmony is the powerhouse of an organization and spirituality is the fuel to that powerhouse. The sense of community with positive organizational structure and clear communication policies helps in providing inner peace and motivation to the employees ${ }^{[19]}$. The organization must provide support to the employee development by their effective leadership skills and individual role clarity ${ }^{[18]}$. Through this management can develop trust and loyalty among workers which results in meaningful work. Harmony is significant for the success of any business and the most appropriate way to bring harmony is by maintaining peace and building trust of the employees. Spirituality is the only way to achieve the state of peace in the environment. When a spiritual person gets in contact with others he creates a positive atmosphere by his strong 'Aura' which influences the people around him. In the same way, the spirituality at the workplace creates a sense of inner peace and satisfaction among the personnel ${ }^{[7]}$. This self-satisfaction motivates them to work for the organization as a whole and not only for themselves. Workplace spirituality develops a sense of pleasure in the minds of employees so that, they remain together and work with patience, giving direction and association at work ${ }^{[1]}$. By aligning self- concept with spiritual identity a sense of belongingness is develop among the community ${ }^{[16]}$. Job satisfaction acts as a tool to manage workload and occupational stress and to create cooperation among the members by developing efficient workermanagement relations ${ }^{[21]}$.

\section{RESEARCH METHOdOLOGY}

The researcher wants to determine the factors affecting of spirituality in harmony at workplace and also to find linkages between them. Hence, the study is descriptive in nature and based on both primary and secondary data. Significant research questions were formed before the commencement of the research study. The study is exploratory in nature.

For the purpose of the study researcher took 100 IT companies of NCR region and their 200 managers. The selection of IT companies and their managers was purely based on non- probability sampling technique like judgmental and convenience. This is because population's geographical location is not even. Hence, as per the convenience of the researcher they choose target sample and the judgment of the researcher plays an important role to find the sample unit in an organization. The data was collected through a self- structured questionnaire. To test the reliability of the questionnaire researcher applied Cronbach Alpha and its value is 0.85 which is more than 0.70. The data collected was analyzed using Casual Loop Diagram. It took around one year i.e. from May 2018 to June 2019 to collect the appropriate data required by the researcher.

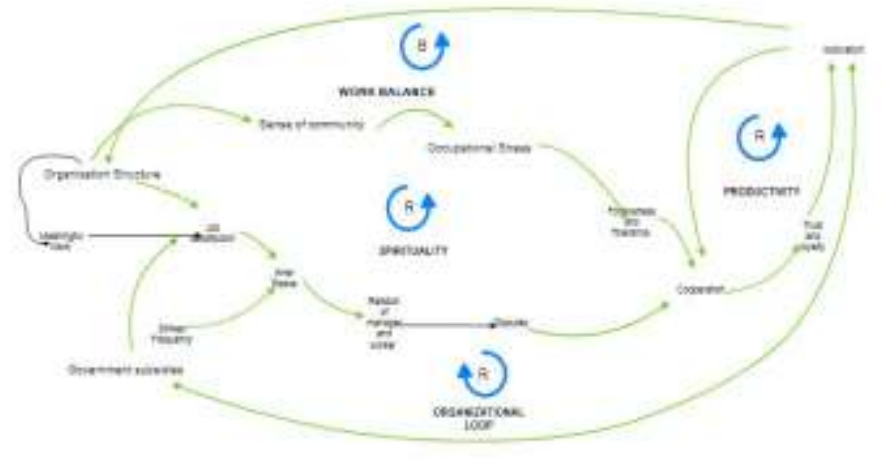

Figure 1: Casual Loop Diagram

\section{PERFORMANCE ANALYSIS OF THE SYSTEM}

The analysis of this system highlights major variables like organisational struture which is further related with meaningful work and job satisfaction. Job satisfaction has its relation with inner peace, and government subsidies. Inner peace effects the strike frequency and managementworkers relations in the organization. Cooperation is multidimensional due to its connection with trust and loyalty, disputes, productivity, forgiveness and tolerance like various dimensions. Motivation effects government subsidies, production and organisational structure in a circular motion. Motivation is emerged as the most important variable that effects the spiritual and harmony level among the workers in the organization. The sense of community acts as a link between organisational structure and occupational stress.

\section{DISCUSSION AND CONCLUSION}

Organizational Structure is positively related to the feeling of sense of community. Management with the sense of community brings all its focus from the other aspects 
towards reducing the occupational stress experienced by their employees at the workplace. This evidences the presence of spirituality at the workplace as self consciousness lies inside us, highlights sense of community in our nature. When there is a lower level of occupational stress in employees, forgiveness and tolerance automatically rises in them because of the presence of spirituality. When one has the tendency to forgive and tolerate others, it results in the creation of a friendly and cooperative environment at workplace. Cooperation has a reinforcing effect on the production of the company as it generates trust and loyalty among the workers. It further motivates them to produce more and generate a cycle of higher production which leads to increased employees morale (motivation). Motivation has a positive connection with government subsidies. As, government provide subsidies to the people it motivates them to work more and earn more. Government subsidies also provide job satisfaction to the employees. Another element that results in providing job satisfaction to the employees is the good organizational structure that results in meaningful work at the workplace. When an employee is satisfied with his job he experiences inner peace which is responsible for his positive outlook. If a person is satisfied from inside apparently he will be satisfies from outside too. This can be achieving by practicing spirituality. As the root idea behind spirituality is to provide inner satisfaction to the people. A satisfied person always maintains cordial relations with others. Through these workers built friendly relations with the management and therefore, results in reduced strike frequency and increased harmony in the working environment. When the relations between the members of the organizations are amicable and supportive then it increases cooperation and decreases disputes in the organization. In this way it can be said that the organizations having spiritual insight with the combination of harmonious working environment witness higher success rates, as they are capable of fulfilling both individual and organizational goals by aligning them at a same platform.

\section{REFERENCES}

[1] Arshad, M., Ahmad, S., (2018). Effect of Workplace Spirituality Paradigm on Students Achievement. American Based Research Journal. Vol-7-Issue-12 Dec-2018 ISSN (2304-7151).

[2] Csutora, M. and Zsóka, A. (2012). Relation of spirituality to happiness, life satisfaction and sustainable lifestyles.

[3] Cavanaugh, M.A. and Noe, R.A. (1999). Antecedents and Consequences of Relational Components of the New Psychological Contract. Journal of Organizational Behavior. Volume 20, Issue 3 .

[4] Chen, S., Fan, Y., Zhang, G., Zhang,Y. (2019). CollectivismOriented Human Resource Management on Team Creativity: Effects of Interpersonal Harmony and Human Resource Management Strength. The International Journal of Human Resource Management. 1466-4399 (Online). DOI: 10.1080/09585192.2019.1640765.
[5] Dandong, A. (2013). Spirituality at Workplace. National Conference on Paradigm for Sustainable Business: People, Planet and Profit. Conference Paper - March 2013.

[6] Dixit, G.K., Dr. Sharma, A. K. (2015). Maintaining Industrial Harmony Through Employee's Engagement -: A Study Report Conduct in Automobile Industry, Delhi NCR. (IJRSI). Volume II, Issue VII, July 2015.

[7] Dr. Chandrasekhar, K.( 2011). Workplace Environment and Its Impact on Organizational Performance in Public Sector Organizations. International Journal of Enterprise Computing and Business Systems Vol. 1 Issue 1 January 2011.

[8] Dr. Kansal, M., Ms. Paliwal, P.( 2012). How The Inner Happiness Generated Through Spirituality Works As A Fuel For Success. International Journal of Marketing, Financial Services \& Management Research. Vol.1 Issue 7, July 2012, ISSN 2277 3622 .

[9] Dr. Makgoba, T. et. al. Understanding Spirituality at Work, Organizations and in Management. Academy of Taiwan Business Management Review.

[10] Dr.Nwinyokpug, N.P ., Okere, Eziuche, A. (2019). Position Power Management and Workplace Harmony in the Construction Sector in Rivers State. International Journal of Business and Management Invention (IJBMI), Volume 8 Issue 01 Ver. II, PP-34-44.

[11] Faribors, B., Fatemeh, A., Hamidreza, H. (2010). The Relationship between Nurses' Spiritual Intelligence and Happiness in Iran. Procedia Social and Behavioral Sciences, 5 (2010) 1556-1561.

[12] Hasannejad, Z., Hasannejad, A. H., Ghodsi, E. (2017). Investigating the Relation of Spirituality in the Workplace with Happiness of Employees. International Journal of Scientific Study. Vol 5 | Issue 3.

[13] Krishnakumar, S. and Neck, C.P. (2002). The "What", "Why" and "How" of Spirituality in the Workplace. Journal of Managerial Psychology. 17, 3; ABI/INFORM Global pg. 153.

[14] Ngunjiri. F. W., Miller, D.W.(2014). Research on Workplace Spirituality, Religion and Ethics: Diverse Perspectives. Academy of Management Annual Meeting Proceedings. DOI: 10.5465/AMBPP.2014.11031symposium.

[15] Nkiinebari, N. P. (2014). Workplace Democracy and Industrial Harmony in Nigeria. International Journal of Innovative Research \& Development. Vol 3 Issue 1.

[16] Piryaei, S., Zare, R. (2013). Workplace Spirituality and Positive Work Attitudes: The Moderating role of Individual Spirituality. Indian Journal of Economics and Development. Vol: 1 | Issue: 4 | April 2013 | ISSN 2320-9836.

[17] Ruona, E.A.W. and Gibson, S.K. (2004). The Making of Twenty- First- Century H.R :An Analysis of the Convergence of HRM, HRD and OD. Human Resource Management. Volume 43, Issue 1.

[18] Subramanian,K. R., Chaubey, D. S., Ramaswamy, R. Harmony - The Soul of Organizations.

[19] Sandhu, D. (2019). Workplace Spirituality and its Impact on Organizational Commitment and Employees' Job Satisfaction amongst Higher Educational Institution Teachers. Indian Journal of Public Health Research and Development. Vol. 10 (3): 132. March 2019.

[20] Thakur, K. And Singh, J. (2016). Spirituality at Workplace: A Conceptual Framework. (I J A B E R), Vol. 14, No. 7, (2016): 5181-5189.

[21] Verma, S. Dr. Chaubey, D. S. (2016). Identifying The Factors Leadings To Workplace Absenteeism And Its Effects On Occupational Stress And Job Satisfaction: An Empirical Study. International Journal of Organizational Behavior \& Management Perspectives @ Pezzottaite Journals. Volume 5, Number 2, April - June' 2016. 